\title{
ÍNDice do volume RBEP
}

Este índice refere-se às matérias do volume 102 (números 260, 261 e 262) da Revista Brasileira de Estudos Pedagógicos. Divide-se em três partes, de acordo com os diferentes pontos de acesso: Assuntos, Autores e Títulos.

Quanto ao Índice de Assuntos:

- os termos usados para indexação são extraídos do Thesaurus Brasileiro de Educação (Brased);

- Cada termo que compõe a entrada de assunto abre uma nova entrada, por exemplo:

ação afirmativa - impacto social - sistema de cotas.

impacto social - ação afirmativa - sistema de cotas.

sistema de cotas - ação afirmativa - impacto social.

Quanto ao Índice de Autores:

- arrolados pelo último sobrenome;

Quanto ao Índice de Títulos:

- os artigos que iniciam o título não são considerados. 



\section{íNDICC DE ASSUNros BBEEP}

Ação afirmativa - impacto social - sistema de cotas.

LOPES, Ronaldo André; SILVA, Guilherme Henrique Gomes da; FERREIRA, Eric Batista. A Lei de Cotas e o acesso à Universidade Federal de Alfenas por estudantes pertencentes a grupos sub-representados. RBEP, Brasília, v. 102, n. 260, p. 148-176, jan./abr. 2021. Seção: Estudos.

Accountability educacional - avaliação da educação - premiação escolar.

COSTA, Anderson Gonçalves; VIDAL, Eloisa Maia. Prêmio Escola Nota Dez no estado do Ceará: concessão, ajustes e responsabilização. RBEP, Brasília, v. 102, n. 261, p. 415-436, maio/ago. 2021. Seção: Estudos.

Aluno superdotado - atendimento individual - educação infantil.

BRAZ, Paula Paulino; RANGNI, Rosemeire de Araújo. Enriquecimento para um aluno com altas habilidades/superdotação na educação infantil. RBEP, Brasília, v. 102, n. 262, p. 802-820, set./dez. 2021. Seção: Relatos de Experiência.

Análise cognitiva de políticas públicas - ensino médio - políticas educacionais - Programa Ensino Médio Inovador.

FERREIRA, Eliza Bartolozzi; TARTAGLIA, Leonara Margotto; BASTOS, Roberta Freire. Políticas inovadoras para o ensino médio no Brasil: um estudo de caso do ProEMI. RBEP, Brasília, v. 102, n. 262, p. 742-763, set./ dez. 2021. Seção: Estudos. 
Anísio Teixeira - planejamento educacional - Plano Nacional de Educação.

AMÂNCIO, Márcia Helena; CASTIONI, Remi. Anísio Teixeira e o Plano Nacional de Educação de 1962 - qualidade social na construção da pessoa humana e da sociedade. RBEP, Brasília, v. 102, n. 262, p. 723-741, set./dez. 2021. Seção: Estudos.

Aprendizagem significativa - gestão ambiental - mapa conceitual metodologias ativas de aprendizagem.

MATOS, Jainer Diogo Vieira; NOLL, Matias; FELICIO, Cinthia Maria; FERREIRA, Júlio César. Prática educativa crítico-reflexiva em Gestão Ambiental e Responsabilidade Social: um relato de experiência. RBEP, Brasília, v. 102, n. 261, p. 564-582, maio/ago. 2021. Seção: Relatos de Experiência.

Atendimento educacional especializado - autismo - educação especial. SANTOS, João Otacilio Libardoni dos; SADIM, Geyse Pattrizzia Teixeira; SCHMIDT, Carlo; MATOS, Maria Almerinda de Souza. O atendimento educacional especializado para os educandos com autismo na rede municipal de Manaus-AM. RBEP, Brasília, v. 102, n. 260, p. 99-119, jan./abr. 2021. Seção: Estudos.

Atendimento individual - aluno superdotado - educação infantil. BRAZ, Paula Paulino; RANGNI, Rosemeire de Araújo. Enriquecimento para um aluno com altas habilidades/superdotação na educação infantil. RBEP, Brasília, v. 102, n. 262, p. 802-820, set./dez. 2021. Seção: Relatos de Experiência.

Autismo - atendimento educacional especializado - educação especial. SANTOS, João Otacilio Libardoni dos; SADIM, Geyse Pattrizzia Teixeira; SCHMIDT, Carlo; MATOS, Maria Almerinda de Souza. O atendimento educacional especializado para os educandos com autismo na rede municipal de Manaus-AM. RBEP, Brasília, v. 102, n. 260, p. 99-119, jan./abr. 2021. Seção: Estudos.

Autismo - educação inclusiva - jogos.

ARAÚJO, Gisele Silva; SEABRA JUNIOR, Manoel Osmar. Elementos fundamentais para o design de jogos digitais com o foco no treino de competências e habilidades de estudantes com transtorno do espectro autista: uma revisão sistemática. RBEP, Brasília, v. 102, n. 260, p. 120-147, jan./abr. 2021. Seção: Estudos.

Autoconfrontação - formação de professores - gravação em vídeo grupo focal - metodologia de pesquisa.

GIORDAN, Miriane Zanetti; SARTI, Flavia Medeiros. Autoconfrontação cruzada em grupo focal: recurso metodológico para pesquisas em Educação. RBEP, Brasília, v. 102, n. 262, p. 707-722, set./dez. 2021. Seção: Estudos. 
Autonomia docente - professor técnico - Sistemas Apostilados de Ensino.

ORTIZ, Gabriel Santos; DENARDIN, Luciano; SAVI NETO, Pedro. Sistemas Apostilados de Ensino e a autonomia ilusória: reflexões à luz de José Contreras. RBEP, Brasília, v. 102, n. 262, p. 607-625, set./dez. 2021. Seção: Estudos.

Avaliação da educação - accountability educacional - premiação escolar.

COSTA, Anderson Gonçalves; VIDAL, Eloisa Maia. Prêmio Escola Nota Dez no estado do Ceará: concessão, ajustes e responsabilização. RBEP, Brasília, v. 102, n. 261, p. 415-436, maio/ago. 2021. Seção: Estudos.

Avaliação da educação - Distrito Federal - formação de professores sistema de ensino estadual.

WELLER, Wivian; SILVA, Cilene Vilarins Cardoso da. Ensino médio público no passado e no presente: visões de docentes de distintas gerações do Distrito Federal. RBEP, Brasília, v. 102, n. 260, p. 63-81, jan./abr. 2021. Seção: Estudos.

Avaliação de impactos - avaliação educacional - educação superior políticas públicas.

ANDRIOLA, Wagner Bandeira; ARAÚJO, Adriana Castro. Avaliação dos impactos do Programa de Apoio a Planos de Expansão e Reestruturação das Universidades Federais Brasileiras. RBEP, Brasília, v. 102, n. 261, p. 437-464, maio/ago. 2021. Seção: Estudos.

Avaliação educacional - avaliação de impactos - educação superior políticas públicas.

ANDRIOLA, Wagner Bandeira; ARAÚJO, Adriana Castro. Avaliação dos impactos do Programa de Apoio a Planos de Expansão e Reestruturação das Universidades Federais Brasileiras. RBEP, Brasília, v. 102, n. 261, p. 437-464, maio/ago. 2021. Seção: Estudos.

Avaliação oficial - demandas cognitivas - Enem - Enade.

ANDRADE, Sammela Rejane de Jesus; FREITAG, Raquel Meister Ko. Objetivos educacionais e avaliações em larga escala na trajetória da educação superior brasileira: Enem, Enade e a complexidade cognitiva na retenção do fluxo. RBEP, Brasília, v. 102, n. 260, p. 177-204, jan./abr. 2021. Seção: Estudos.

Brincar e jogar - democracia - educação cidadã - infância. SILVEIRA, Carmem Lúcia Albrecht; LAUER, Munir José; ESQUINSANI, Rosimar Serena Siqueira. O sentido do brincar e do jogar na infância humana como fundamentos para a construção da democracia social. RBEP, Brasília, v. 102, n. 262, p. 787-801, set./dez. 2021. Seção: Estudos. 


\section{Comunicação - John Dewey - retórica.}

SILVA, Tatiane da; CUNHA, Marcus Vinicius da. Educação, comunicação e imaginação em John Dewey: contribuições teóricas e práticas. RBEP, Brasília, v. 102, n. 262, p. 626-641, set./dez. 2021. Seção: Estudos.

\section{Comunidade - educação no campo - memória histórica.}

LOPES, Suzana Gomes; SILVA, Alexandre Leite dos Santos; SOUSA, Caroline Lucena de. Vivências e memórias entre a Escola Monsenhor Lopes e a Comunidade Forte. RBEP, Brasília, v. 102, n. 260, p. 43-62, jan./abr. 2021. Seção: Estudos.

\section{Concepções de saúde - currículo - formação docente - modelo KVP -} produção científica.

SCHWINGEL, Tatiane Cristina Possel Greter; ARAÚJO, Maria Cristina Pansera de. Educação em Saúde na escola: conhecimentos, valores e práticas na formação de professores. RBEP, Brasília, v. 102, n. 261, p. 465-485, maio/ago. 2021. Seção: Estudos.

Cultura tradicional - educação no meio rural - saúde e educação. ROSA, Walquíria Miranda; GALVÃO, Ana Maria de Oliveira. Práticas de cura, saberes tradicionais e conhecimentos escolares: um estudo sobre uma comunidade rural de Minas Gerais (1940-1970). RBEP, Brasília, v. 102, n. 260, p. 23-42, jan./abr. 2021. Seção: Estudos.

Currículo - concepções de saúde - formação docente - modelo KVP produção científica.

SCHWINGEL, Tatiane Cristina Possel Greter; ARAÚJO, Maria Cristina Pansera de. Educação em Saúde na escola: conhecimentos, valores e práticas na formação de professores. RBEP, Brasília, v. 102, n. 261, p. 465-485, maio/ago. 2021. Seção: Estudos.

\section{Currículo - curso de Pedagogia - educação não escolar.}

SOUZA, Mariana Aparecida Serejo de. O lugar da educação não escolar nos currículos de Pedagogia. RBEP, Brasília, v. 102, n. 262, p. 689-706, set./ dez. 2021. Seção: Estudos.

Curso de Pedagogia - currículo - educação não escolar.

SOUZA, Mariana Aparecida Serejo de. O lugar da educação não escolar nos currículos de Pedagogia. RBEP, Brasília, v. 102, n. 262, p. 689-706, set./ dez. 2021. Seção: Estudos.

Debates em educação - educação contra a barbárie - resenhas.

SILVA JUNIOR, Jonas Alves da. Um livro de combate contra a barbárie na educação brasileira. RBEP, Brasília, v. 102, n. 260, p. 309-314, jan./abr. 2021. Seção: Resenhas. 
Deficiência visual - educação inclusiva - entrevista - ensino de Língua Portuguesa.

BOULITREAU, Paula Roberta Paschoal; BARROS, José Batista de; ROSA, Adriana Letícia Torres da; MACEDO, Bárbara Cristina Oliveira. Inclusão e acessibilidade na escola: conhecendo a deficiência visual nas aulas de Língua Portuguesa. RBEP, Brasília, v. 102, n. 261, p. 521-542, maio/ago. 2021. Seção: Relatos de Experiência.

Demandas cognitivas - avaliação oficial - Enem - Enade.

ANDRADE, Sammela Rejane de Jesus; FREITAG, Raquel Meister Ko. Objetivos educacionais e avaliações em larga escala na trajetória da educação superior brasileira: Enem, Enade e a complexidade cognitiva na retenção do fluxo. RBEP, Brasília, v. 102, n. 260, p. 177-204, jan./abr. 2021. Seção: Estudos.

Democracia - brincar e jogar - educação cidadã - infância.

SILVEIRA, Carmem Lúcia Albrecht; LAUER, Munir José; ESQUINSANI, Rosimar Serena Siqueira. O sentido do brincar e do jogar na infância humana como fundamentos para a construção da democracia social. RBEP, Brasília, v. 102, n. 262, p. 787-801, set./dez. 2021. Seção: Estudos.

Diálogo - escola básica - interculturalidade.

SANTOS, Rosane Barreto Ramos dos; QUEIROZ, Paulo Pires de. A complexa relação humana no espaço escolar: o que indisciplina, currículo e cultura têm a nos revelar? RBEP, Brasília, v. 102, n. 261, p. 339-356, maio/ago. 2021. Seção: Estudos.

Diáspora africana - recepção literária - relações étnico-raciais.

DIAS, Thiago Leandro da Silva; SOUZA, Rogério Santos. Tessitura e subsídios de um produto literário infantojuvenil para o ensino da história e cultura africana e afro-brasileira. RBEP, Brasília, v. 102, n. 261, p. 376397, maio/ago. 2021. Seção: Estudos.

Didática - ensino de Química - formação docente.

MARTINS, Evellyn Priscila Nunes; TEIXEIRA JÚNIOR, José Gonçalves. Análise das contribuições da disciplina de Didática Geral para a formação de professores de Química. RBEP, Brasília, v. 102, n. 261, p. 486-502, maio/ ago. 2021. Seção: Estudos.

Diferença cultural - docência - educação intercultural - escola de fronteira.

WESCHENFELDER, Viviane Inês; OLIVEIRA, Joelma Fernandes de; FABRIS, Elí Terezinha Henn. Docência e relações interculturais na fronteira BrasilVenezuela. RBEP, Brasília, v. 102, n. 262, p. 668-688, set./dez. 2021. Seção: Estudos. 
Distrito Federal - avaliação da educação - formação de professores sistema de ensino estadual.

WELLER, Wivian; SILVA, Cilene Vilarins Cardoso da. Ensino médio público no passado e no presente: visões de docentes de distintas gerações do Distrito Federal. RBEP, Brasília, v. 102, n. 260, p. 63-81, jan./abr. 2021. Seção: Estudos.

Docência - diferença cultural - educação intercultural - escola de fronteira.

WESCHENFELDER, Viviane Inês; OLIVEIRA, Joelma Fernandes de; FABRIS, Elí Terezinha Henn. Docência e relações interculturais na fronteira BrasilVenezuela. RBEP, Brasília, v. 102, n. 262, p. 668-688, set./dez. 2021. Seção: Estudos.

Educação cidadã - brincar e jogar - democracia - infância.

SILVEIRA, Carmem Lúcia Albrecht; LAUER, Munir José; ESQUINSANI, Rosimar Serena Siqueira. O sentido do brincar e do jogar na infância humana como fundamentos para a construção da democracia social. RBEP, Brasília, v. 102, n. 262, p. 787-801, set./dez. 2021. Seção: Estudos.

Educação contra a barbárie - resenha - debates em educação.

SILVA JUNIOR, Jonas Alves da. Um livro de combate contra a barbárie na educação brasileira. RBEP, Brasília, v. 102, n. 260, p. 309-314, jan./abr. 2021. Seção: Resenhas.

Educação de jovens e adultos - estatística - interpretação de gráficos. LIMA, Izauriana Borges; SELVA, Ana Coêlho Vieira. Interpretação de gráficos de barras na educação de jovens e adultos. RBEP, Brasília, v. 102, n. 260, p. 218-242, jan./abr. 2021. Seção: Estudos.

Educação do campo - princípios agroecológicos - tecnologia social. DOMINGUES, Sérgio; SANTOS JÚNIOR, Cezário Ferreira dos; NUNES, Aline; BONADIMAN, Ariel. Agroecologia e Pedagogia da Alternância: um estudo de caso da Escola Tecnológica de Fraiburgo, Santa Catarina. RBEP, Brasília, v. 102, n. 262, p. 764-786, set./dez. 2021. Seção: Estudos.

Educação especial - atendimento educacional especializado - autismo. SANTOS, João Otacilio Libardoni dos; SADIM, Geyse Pattrizzia Teixeira; SCHMIDT, Carlo; MATOS, Maria Almerinda de Souza. O atendimento educacional especializado para os educandos com autismo na rede municipal de Manaus-AM. RBEP, Brasília, v. 102, n. 260, p. 99-119, jan./abr. 2021. Seção: Estudos.

Educação especial - educação inclusiva - formação profissional. VILARONGA, Carla Ariela Rios; SILVA, Michele Oliveira da; FRANCO, Ana Beatriz Momesso; RIOS, Gabriela Alias. Inclusão escolar e atuação dos Núcleos de Apoio às Pessoas com Necessidades Educacionais Específicas no Instituto Federal de São Paulo. RBEP, Brasília, v. 102, n. 260, p. 283-308, jan./abr. 2021. Seção: Relatos de Experiência. 
Educação física - esportes de aventura - meio ambiente e educação. TRIANI, Felipe da Silva; SOUZA, Anna Carolina Carvalho de; MAGALHAES JÚNIOR, Carlos Alberto de Oliveira; TELLES, Silvio de Cassio Costa. Representações sociais de graduandos em Educação Física sobre o meio ambiente e a relação homem, esporte e natureza. RBEP, Brasília, v. 102, n. 260, p. 205-217, jan./abr. 2021. Seção: Estudos.

Educação inclusiva - autismo - jogos.

ARAUJO, Gisele Silva; SEABRA JUNIOR, Manoel Osmar. Elementos fundamentais para o design de jogos digitais com o foco no treino de competências e habilidades de estudantes com transtorno do espectro autista: uma revisão sistemática. RBEP, Brasília, v. 102, n. 260, p. 120-147, jan./abr. 2021. Seção: Estudos.

Educação inclusiva - deficiência visual - entrevista - ensino de Língua Portuguesa.

BOULITREAU, Paula Roberta Paschoal; BARROS, José Batista de; ROSA, Adriana Letícia Torres da; MACEDO, Bárbara Cristina Oliveira. Inclusão e acessibilidade na escola: conhecendo a deficiência visual nas aulas de Língua Portuguesa. RBEP, Brasília, v. 102, n. 261, p. 521-542, maio/ago. 2021. Seção: Relatos de Experiência.

Educação inclusiva - educação especial - formação profissional. VILARONGA, Carla Ariela Rios; SILVA, Michele Oliveira da; FRANCO, Ana Beatriz Momesso; RIOS, Gabriela Alias. Inclusão escolar e atuação dos Núcleos de Apoio às Pessoas com Necessidades Educacionais Específicas no Instituto Federal de São Paulo. RBEP, Brasília, v. 102, n. 260, p. 283-308, jan./abr. 2021. Seção: Relatos de Experiência.

Educação inclusiva - percepção docente - transtorno da habilidade motora.

MAIA, Samia Darcila Barros; FERREIRA, Lúcio Fernandes; SOUZA, Cleverton José Farias de. Percepção do docente e o Transtorno do Desenvolvimento da Coordenação (TDC): um estudo de revisão integrativa. RBEP, Brasília, v. 102, n. 261, p. 398-414, maio/ago. 2021. Seção: Estudos.

Educação infantil - aluno superdotado - atendimento individual.

BRAZ, Paula Paulino; RANGNI, Rosemeire de Araújo. Enriquecimento para um aluno com altas habilidades/superdotação na educação infantil. RBEP, Brasília, v. 102, n. 262, p. 802-820, set./dez. 2021. Seção: Relatos de Experiência.

Educação intercultural - diferença cultural - docência - escola de fronteira.

WESCHENFELDER, Viviane Inês; OLIVEIRA, Joelma Fernandes de; FABRIS, Elí Terezinha Henn. Docência e relações interculturais na fronteira BrasilVenezuela. RBEP, Brasília, v. 102, n. 262, p. 668-688, set./dez. 2021. Seção: Estudos. 
Educação não escolar - currículo - curso de Pedagogia.

SOUZA, Mariana Aparecida Serejo de. O lugar da educação não escolar nos currículos de Pedagogia. RBEP, Brasília, v. 102, n. 262, p. 689-706, set./ dez. 2021. Seção: Estudos.

\section{Educação no campo - comunidade - memória histórica.}

LOPES, Suzana Gomes; SILVA, Alexandre Leite dos Santos; SOUSA, Caroline Lucena de. Vivências e memórias entre a Escola Monsenhor Lopes e a Comunidade Forte. RBEP, Brasília, v. 102, n. 260, p. 43-62, jan./abr. 2021. Seção: Estudos.

Educação no meio rural - cultura tradicional - saúde e educação. ROSA, Walquíria Miranda; GALVÃO, Ana Maria de Oliveira. Práticas de cura, saberes tradicionais e conhecimentos escolares: um estudo sobre uma comunidade rural de Minas Gerais (1940-1970). RBEP, Brasília, v. 102, n. 260, p. 23-42, jan./abr. 2021. Seção: Estudos.

Educação superior - avaliação de impactos - avaliação educacional políticas públicas.

ANDRIOLA, Wagner Bandeira; ARAÚJO, Adriana Castro. Avaliação dos impactos do Programa de Apoio a Planos de Expansão e Reestruturação das Universidades Federais Brasileiras. RBEP, Brasília, v. 102, n. 261, p. 437-464, maio/ago. 2021. Seção: Estudos.

\section{Enade - Enem - avaliação oficial - demandas cognitivas.}

ANDRADE, Sammela Rejane de Jesus; FREITAG, Raquel Meister Ko. Objetivos educacionais e avaliações em larga escala na trajetória da educação superior brasileira: Enem, Enade e a complexidade cognitiva na retenção do fluxo. RBEP, Brasília, v. 102, n. 260, p. 177-204, jan./abr. 2021. Seção: Estudos.

Enem - avaliação oficial - demandas cognitivas - Enade.

ANDRADE, Sammela Rejane de Jesus; FREITAG, Raquel Meister Ko. Objetivos educacionais e avaliações em larga escala na trajetória da educação superior brasileira: Enem, Enade e a complexidade cognitiva na retenção do fluxo. RBEP, Brasília, v. 102, n. 260, p. 177-204, jan./abr. 2021. Seção: Estudos.

Ensino de Geografia - estudo do meio - formação de professores. CACETE, Núria Hanglei; DURÃES, Fabíola Alice dos Anjos; MOURA, Cleberson Henrique de. O estudo do meio como opção metodológica na formação inicial de professores/as de Geografia: relato de experiência nas cidades históricas do Vale do Rio Paraíba do Sul Paulista. RBEP, Brasília, v. 102, n. 261, p. 543-563, maio/ago. 2021. Seção: Relatos de Experiência. 
Ensino de Língua Portuguesa - deficiência visual - educação inclusiva entrevista.

BOULITREAU, Paula Roberta Paschoal; BARROS, José Batista de; ROSA, Adriana Letícia Torres da; MACEDO, Bárbara Cristina Oliveira. Inclusão e acessibilidade na escola: conhecendo a deficiência visual nas aulas de Língua Portuguesa. RBEP, Brasília, v. 102, n. 261, p. 521-542, maio/ago. 2021. Seção: Relatos de Experiência.

Ensino de Química - didática - formação docente.

MARTINS, Evellyn Priscila Nunes; TEIXEIRA JÚNIOR, José Gonçalves. Análise das contribuições da disciplina de Didática Geral para a formação de professores de Química. RBEP, Brasília, v. 102, n. 261, p. 486-502, maio/ ago. 2021. Seção: Estudos.

Ensino médio - análise cognitiva de políticas públicas - políticas educacionais - Programa Ensino Médio Inovador.

FERREIRA, Eliza Bartolozzi; TARTAGLIA, Leonara Margotto; BASTOS, Roberta Freire. Políticas inovadoras para o ensino médio no Brasil: um estudo de caso do ProEMI. RBEP, Brasília, v. 102, n. 262, p. 742-763, set./ dez. 2021. Seção: Estudos.

Ensino médio - juventude - transição para a vida adulta.

LEBOURG, Elodia Honse; COUTRIM, Rosa Maria da Exaltação; SILVA, Luciano Campos da. Juventude e transição para o ensino médio: desafios e projetos de futuro. RBEP, Brasília, v. 102, n. 260, p. 82-98, jan./abr. 2021. Seção: Estudos.

Ensino superior - formação de professores - identidade profissional. RECH, Rose Aparecida Colognese; BOFF, Eva Teresinha de Oliveira. A constituição da identidade docente e suas implicações nas práticas educativas de professores de uma universidade comunitária. RBEP, Brasília, v. 102, n. 262, p. 642-667, set./dez. 2021. Seção: Estudos.

Ensino superior intercultural - formação de professores indígenas licenciaturas interculturais.

SANCHEZ, Laura Marcela Cubides; LEAL, Fabiana Soares Fernandes. "Licenciatura em Educação Básica Intercultural": avanços, desafios e potencialidades na formação superior de professores indígenas. RBEP, Brasília, v. 102, n. 261, p. 357-375, maio/ago. 2021. Seção: Estudos.

Ensino técnico - extensão rural - prática social - vivências.

FACCO, Hector dos Santos; DISKA, Nathana Marina; SILVA, Gustavo Pinto da. As vivências como metodologia de ensino da extensão rural: a aproximação entre estudantes e agricultores para a compreensão da realidade social. RBEP, Brasília, v. 102, n. 262, p. 821-838, set./dez. 2021. Seção: Relatos de Experiência. 
Entrevista - deficiência visual - educação inclusiva - ensino de Língua Portuguesa.

BOULITREAU, Paula Roberta Paschoal; BARROS, José Batista de; ROSA, Adriana Letícia Torres da; MACEDO, Bárbara Cristina Oliveira. Inclusão e acessibilidade na escola: conhecendo a deficiência visual nas aulas de Língua Portuguesa. RBEP, Brasília, v. 102, n. 261, p. 521-542, maio/ago. 2021. Seção: Relatos de Experiência.

Escola básica - diálogo - interculturalidade.

SANTOS, Rosane Barreto Ramos dos; QUEIROZ, Paulo Pires de. A complexa relação humana no espaço escolar: o que indisciplina, currículo e cultura têm a nos revelar? RBEP, Brasília, v. 102, n. 261, p. 339-356, maio/ago. 2021. Seção: Estudos.

Escola de fronteira - diferença cultural - docência - educação intercultural.

WESCHENFELDER, Viviane Inês; OLIVEIRA, Joelma Fernandes de; FABRIS, Elí Terezinha Henn. Docência e relações interculturais na fronteira BrasilVenezuela. RBEP, Brasília, v. 102, n. 262, p. 668-688, set./dez. 2021. Seção: Estudos.

Esportes de aventura - educação física - meio ambiente e educação. TRIANI, Felipe da Silva; SOUZA, Anna Carolina Carvalho de; MAGALHÃES JÚNIOR, Carlos Alberto de Oliveira; TELLES, Silvio de Cassio Costa. Representações sociais de graduandos em Educação Física sobre o meio ambiente e a relação homem, esporte e natureza. RBEP, Brasília, v. 102, n. 260, p. 205-217, jan./abr. 2021. Seção: Estudos.

Estatística - educação de jovens e adultos - interpretação de gráficos. LIMA, Izauriana Borges; SELVA, Ana Coêlho Vieira. Interpretação de gráficos de barras na educação de jovens e adultos. RBEP, Brasília, v. 102, n. 260, p. 218-242, jan./abr. 2021. Seção: Estudos.

\section{Estudo do meio - ensino de Geografia - formação de professores.}

CACETE, Núria Hanglei; DURÃES, Fabíola Alice dos Anjos; MOURA, Cleberson Henrique de. O estudo do meio como opção metodológica na formação inicial de professores/as de Geografia: relato de experiência nas cidades históricas do Vale do Rio Paraíba do Sul Paulista. RBEP, Brasília, v. 102, n. 261, p. 543-563, maio/ago. 2021. Seção: Relatos de Experiência.

Extensão rural - ensino técnico - prática social - vivências.

FACCO, Hector dos Santos; DISKA, Nathana Marina; SILVA, Gustavo Pinto da. As vivências como metodologia de ensino da extensão rural: a aproximação entre estudantes e agricultores para a compreensão da realidade social. RBEP, Brasília, v. 102, n. 262, p. 821-838, set./dez. 2021. Seção: Relatos de Experiência. 
Formação de professores - ensino de Geografia - estudo do meio. CACETE, Núria Hanglei; DURÃES, Fabíola Alice dos Anjos; MOURA, Cleberson Henrique de. O estudo do meio como opção metodológica na formação inicial de professores/as de Geografia: relato de experiência nas cidades históricas do Vale do Rio Paraíba do Sul Paulista. RBEP, Brasília, v. 102, n. 261, p. 543-563, maio/ago. 2021. Seção: Relatos de Experiência.

Formação de professores - autoconfrontação - gravação em vídeo grupo focal - metodologia de pesquisa.

GIORDAN, Miriane Zanetti; SARTI, Flavia Medeiros. Autoconfrontação cruzada em grupo focal: recurso metodológico para pesquisas em Educação. RBEP, Brasília, v. 102, n. 262, p. 707-722, set./dez. 2021. Seção: Estudos.

Formação de professores - avaliação da educação - Distrito Federal sistema de ensino estadual.

WELLER, Wivian; SILVA, Cilene Vilarins Cardoso da. Ensino médio público no passado e no presente: visões de docentes de distintas gerações do Distrito Federal. RBEP, Brasília, v. 102, n. 260, p. 63-81, jan./abr. 2021. Seção: Estudos.

Formação de professores - ensino superior - identidade profissional. RECH, Rose Aparecida Colognese; BOFF, Eva Teresinha de Oliveira. A constituição da identidade docente e suas implicações nas práticas educativas de professores de uma universidade comunitária. RBEP, Brasília, v. 102, n. 262, p. 642-667, set./dez. 2021. Seção: Estudos.

Formação de professores - licenciatura - metodologia de pesquisa. LIBARDI Suzana Santos; GOMES, Carmelita Maria; ARAUJO, Ana Paula Sandes. A colaboração em pesquisa como ferramenta metodológica para formação de professores/as na licenciatura. RBEP, Brasília, v. 102, n. 260, p. 243-262, jan./abr. 2021. Seção: Relatos de Experiência.

Formação de professores indígenas - ensino superior intercultural licenciaturas interculturais.

SANCHEZ, Laura Marcela Cubides; LEAL, Fabiana Soares Fernandes.

"Licenciatura em Educação Básica Intercultural": avanços, desafios e potencialidades na formação superior de professores indígenas. RBEP, Brasília, v. 102, n. 261, p. 357-375, maio/ago. 2021. Seção: Estudos.

Formação docente - concepções de saúde - currículo - modelo KVP produção científica.

SCHWINGEL, Tatiane Cristina Possel Greter; ARAÚJO, Maria Cristina Pansera de. Educação em Saúde na escola: conhecimentos, valores e práticas na formação de professores. RBEP, Brasília, v. 102, n. 261, p. 465-485, maio/ago. 2021. Seção: Estudos. 
Formação docente - didática - ensino de Química.

MARTINS, Evellyn Priscila Nunes; TEIXEIRA JÚNIOR, José Gonçalves. Análise das contribuições da disciplina de Didática Geral para a formação de professores de Química. RBEP, Brasília, v. 102, n. 261, p. 486-502, maio/ ago. 2021. Seção: Estudos.

Formação profissional - educação especial - educação inclusiva. VILAR ONGA, Carla Ariela Rios; SILVA, Michele Oliveira da; FRANCO, Ana Beatriz Momesso; RIOS, Gabriela Alias. Inclusão escolar e atuação dos Núcleos de Apoio às Pessoas com Necessidades Educacionais Específicas no Instituto Federal de São Paulo. RBEP, Brasília, v. 102, n. 260, p. 283-308, jan./abr. 2021. Seção: Relatos de Experiência.

Funções psicológicas superiores - produção de textos - revisão e reescrita.

STEVANATO, Patrícia de Araujo Abucarma; SHIMAZAKI, Elsa Midori. Produção de texto no $3^{\circ}$ ano do ensino fundamental: revisão e reescrita no desenvolvimento das funções psicológicas superiores. RBEP, Brasília, v. 102, n. 260, p. 263-282, jan./abr. 2021. Seção: Relatos de Experiência.

Gestão ambiental - aprendizagem significativa - mapa conceitual metodologias ativas de aprendizagem.

MATOS, Jainer Diogo Vieira; NOLL, Matias; FELICIO, Cinthia Maria; FERREIRA, Júlio César. Prática educativa crítico-reflexiva em Gestão Ambiental e Responsabilidade Social: um relato de experiência. RBEP, Brasília, v. 102, n. 261, p. 564-582, maio/ago. 2021. Seção: Relatos de Experiência.

Gravação em vídeo - autoconfrontação - formação de professores grupo focal - metodologia de pesquisa.

GIORDAN, Miriane Zanetti; SARTI, Flavia Medeiros. Autoconfrontação cruzada em grupo focal: recurso metodológico para pesquisas em Educação. RBEP, Brasília, v. 102, n. 262, p. 707-722, set./dez. 2021. Seção: Estudos.

Grupo focal - autoconfrontação - formação de professores - gravação em vídeo - metodologia de pesquisa.

GIORDAN, Miriane Zanetti; SARTI, Flavia Medeiros. Autoconfrontação cruzada em grupo focal: recurso metodológico para pesquisas em Educação. RBEP, Brasília, v. 102, n. 262, p. 707-722, set./dez. 2021. Seção: Estudos.

Identidade profissional - ensino superior - formação de professores. RECH, Rose Aparecida Colognese; BOFF, Eva Teresinha de Oliveira. A constituição da identidade docente e suas implicações nas práticas educativas de professores de uma universidade comunitária. RBEP, Brasília, v. 102, n. 262, p. 642-667, set./dez. 2021. Seção: Estudos. 
Impacto social - ação afirmativa - sistema de cotas.

LOPES, Ronaldo André; SILVA, Guilherme Henrique Gomes da; FERREIRA, Eric Batista. A Lei de Cotas e o acesso à Universidade Federal de Alfenas por estudantes pertencentes a grupos sub-representados. RBEP, Brasília, v. 102, n. 260, p. 148-176, jan./abr. 2021. Seção: Estudos.

Infância - brincar e jogar - democracia - educação cidadã .

SILVEIRA, Carmem Lúcia Albrecht; LAUER, Munir José; ESQUINSANI, Rosimar Serena Siqueira. O sentido do brincar e do jogar na infância humana como fundamentos para a construção da democracia social. RBEP, Brasília, v. 102, n. 262, p. 787-801, set./dez. 2021. Seção: Estudos.

Interculturalidade - diálogo - escola básica.

SANTOS, Rosane Barreto Ramos dos; QUEIROZ, Paulo Pires de. A complexa relação humana no espaço escolar: o que indisciplina, currículo e cultura têm a nos revelar? RBEP, Brasília, v. 102, n. 261, p. 339-356, maio/ago. 2021. Seção: Estudos.

Interpretação de gráficos - educação de jovens e adultos - estatística. LIMA, Izauriana Borges; SELVA, Ana Coêlho Vieira. Interpretação de gráficos de barras na educação de jovens e adultos. RBEP, Brasília, v. 102, n. 260, p. 218-242, jan./abr. 2021. Seção: Estudos.

Jogos - autismo - educação inclusiva.

ARAUUO, Gisele Silva; SEABRA JUNIOR, Manoel Osmar. Elementos fundamentais para o design de jogos digitais com o foco no treino de competências e habilidades de estudantes com transtorno do espectro autista: uma revisão sistemática. RBEP, Brasília, v. 102, n. 260, p. 120-147, jan./abr. 2021. Seção: Estudos.

John Dewey - comunicação - retórica.

SILVA, Tatiane da; CUNHA, Marcus Vinicius da. Educação, comunicação e imaginação em John Dewey: contribuições teóricas e práticas. RBEP, Brasília, v. 102, n. 262, p. 626-641, set./dez. 2021. Seção: Estudos.

Juventude - ensino médio - transição para a vida adulta.

LEBOURG, Elodia Honse; COUTRIM, Rosa Maria da Exaltação; SILVA, Luciano Campos da. Juventude e transição para o ensino médio: desafios e projetos de futuro. RBEP, Brasília, v. 102, n. 260, p. 82-98, jan./abr. 2021. Seção: Estudos.

Letramentos locais e globais - Pibid - projeto de letramento.

GESSER, Andressa Regiane. Projetos de letramento e suas contribuições para a ampliação dos conhecimentos locais e globais sobre a diversidade cultural brasileira. RBEP, Brasília, v. 102, n. 261, p. 503-520, maio/ago. 2021. Seção: Relatos de Experiência. 
Licenciatura - formação de professores - metodologia de pesquisa. LIBARDI Suzana Santos; GOMES, Carmelita Maria; ARAUJO, Ana Paula Sandes. A colaboração em pesquisa como ferramenta metodológica para formação de professores/as na licenciatura. RBEP, Brasília, v. 102, n. 260, p. 243-262, jan./abr. 2021. Seção: Relatos de Experiência.

Licenciaturas interculturais - ensino superior intercultural - formação de professores indígenas.

SANCHEZ, Laura Marcela Cubides; LEAL, Fabiana Soares Fernandes. "Licenciatura em Educação Básica Intercultural": avanços, desafios e potencialidades na formação superior de professores indígenas. RBEP, Brasília, v. 102, n. 261, p. 357-375, maio/ago. 2021. Seção: Estudos.

Mapa conceitual - aprendizagem significativa - gestão ambiental metodologias ativas de aprendizagem.

MATOS, Jainer Diogo Vieira; NOLL, Matias; FELICIO, Cinthia Maria; FERREIRA, Júlio César. Prática educativa crítico-reflexiva em Gestão Ambiental e Responsabilidade Social: um relato de experiência. RBEP, Brasília, v. 102, n. 261, p. 564-582, maio/ago. 2021. Seção: Relatos de Experiência.

Meio ambiente e educação - educação física - esportes de aventura. TRIANI, Felipe da Silva; SOUZA, Anna Carolina Carvalho de; MAGALHÃES JÚNIOR, Carlos Alberto de Oliveira; TELLES, Silvio de Cassio Costa. Representações sociais de graduandos em Educação Física sobre o meio ambiente e a relação homem, esporte e natureza. RBEP, Brasília, v. 102, n. 260, p. 205-217, jan./abr. 2021. Seção: Estudos.

Memória histórica - comunidade - educação no campo.

LOPES, Suzana Gomes; SILVA, Alexandre Leite dos Santos; SOUSA, Caroline Lucena de. Vivências e memórias entre a Escola Monsenhor Lopes e a Comunidade Forte. RBEP, Brasília, v. 102, n. 260, p. 43-62, jan./abr. 2021. Seção: Estudos.

Metodologia de pesquisa - autoconfrontação - formação de professores - gravação em vídeo - grupo focal.

GIORDAN, Miriane Zanetti; SARTI, Flavia Medeiros. Autoconfrontação cruzada em grupo focal: recurso metodológico para pesquisas em Educação. RBEP, Brasília, v. 102, n. 262, p. 707-722, set./dez. 2021. Seção: Estudos.

Metodologia de pesquisa - formação de professores - licenciatura. LIBARDI Suzana Santos; GOMES, Carmelita Maria; ARAUJO, Ana Paula Sandes. A colaboração em pesquisa como ferramenta metodológica para formação de professores/as na licenciatura. RBEP, Brasília, v. 102, n. 260, p. 243-262, jan./abr. 2021. Seção: Relatos de Experiência. 
Metodologias ativas de aprendizagem - aprendizagem significativa mapa conceitual - gestão ambiental.

MATOS, Jainer Diogo Vieira; NOLL, Matias; FELICIO, Cinthia Maria; FERREIRA, Júlio César. Prática educativa crítico-reflexiva em Gestão Ambiental e Responsabilidade Social: um relato de experiência. RBEP, Brasília, v. 102, n. 261, p. 564-582, maio/ago. 2021. Seção: Relatos de Experiência.

Modelo KVP - concepções de saúde - currículo - formação docente produção científica.

SCHWINGEL, Tatiane Cristina Possel Greter; ARAÚJO, Maria Cristina Pansera de. Educação em Saúde na escola: conhecimentos, valores e práticas na formação de professores. RBEP, Brasília, v. 102, n. 261, p. 465-485, maio/ago. 2021. Seção: Estudos.

Percepção docente - educação inclusiva - transtorno da habilidade motora.

MAIA, Samia Darcila Barros; FERREIRA, Lúcio Fernandes; SOUZA, Cleverton José Farias de. Percepção do docente e o Transtorno do Desenvolvimento da Coordenação (TDC): um estudo de revisão integrativa. RBEP, Brasília, v. 102, n. 261, p. 398-414, maio/ago. 2021. Seção: Estudos.

Pibid - letramentos locais e globais - projeto de letramento.

GESSER, Andressa Regiane. Projetos de letramento e suas contribuições para a ampliação dos conhecimentos locais e globais sobre a diversidade cultural brasileira. RBEP, Brasília, v. 102, n. 261, p. 503-520, maio/ago. 2021. Seção: Relatos de Experiência.

Planejamento educacional - Anísio Teixeira - Plano Nacional de Educação.

AMÂNCIO, Márcia Helena; CASTIONI, Remi. Anísio Teixeira e o Plano Nacional de Educação de 1962 - qualidade social na construção da pessoa humana e da sociedade. RBEP, Brasília, v. 102, n. 262, p. 723-741, set./dez. 2021. Seção: Estudos.

Plano Nacional de Educação - Anísio Teixeira - planejamento educacional.

AMÂNCIO, Márcia Helena; CASTIONI, Remi. Anísio Teixeira e o Plano Nacional de Educação de 1962 - qualidade social na construção da pessoa humana e da sociedade. RBEP, Brasília, v. 102, n. 262, p. 723-741, set./dez. 2021. Seção: Estudos.

Políticas educacionais - análise cognitiva de políticas públicas - ensino médio - Programa Ensino Médio Inovador.

FERREIRA, Eliza Bartolozzi; TARTAGLIA, Leonara Margotto; BASTOS, Roberta Freire. Políticas inovadoras para o ensino médio no Brasil: um estudo de caso do ProEMI. RBEP, Brasília, v. 102, n. 262, p. 742-763, set./ dez. 2021. Seção: Estudos. 
Políticas públicas - avaliação educacional - avaliação de impactos educação superior.

ANDRIOLA, Wagner Bandeira; ARAÚJO, Adriana Castro. Avaliação dos impactos do Programa de Apoio a Planos de Expansão e Reestruturação das Universidades Federais Brasileiras. RBEP, Brasília, v. 102, n. 261, p. 437-464, maio/ago. 2021. Seção: Estudos.

Prática social - ensino técnico - extensão rural - vivências.

FACCO, Hector dos Santos; DISKA, Nathana Marina; SILVA, Gustavo Pinto da. As vivências como metodologia de ensino da extensão rural: a aproximação entre estudantes e agricultores para a compreensão da realidade social. RBEP, Brasília, v. 102, n. 262, p. 821-838, set./dez. 2021. Seção: Relatos de Experiência.

Premiação escolar - accountability educacional - avaliação da educação. COSTA, Anderson Gonçalves; VIDAL, Eloisa Maia. Prêmio Escola Nota Dez no estado do Ceará: concessão, ajustes e responsabilização. RBEP, Brasília, v. 102, n. 261, p. 415-436, maio/ago. 2021. Seção: Estudos.

Princípios agroecológicos - educação do campo - tecnologia social. DOMINGUES, Sérgio; SANTOS JÚNIOR, Cezário Ferreira dos; NUNES, Aline; BONADIMAN, Ariel. Agroecologia e Pedagogia da Alternância: um estudo de caso da Escola Tecnológica de Fraiburgo, Santa Catarina. RBEP, Brasília, v. 102, n. 262, p. 764-786, set./dez. 2021. Seção: Estudos.

Produção científica - Modelo KVP - concepções de saúde - currículo formação docente.

SCHWINGEL, Tatiane Cristina Possel Greter; ARAÚJO, Maria Cristina Pansera de. Educação em Saúde na escola: conhecimentos, valores e práticas na formação de professores. RBEP, Brasília, v. 102, n. 261, p. 465-485, maio/ago. 2021. Seção: Estudos.

Produção de textos-funções psicológicas superiores - revisão e reescrita. STEVANATO, Patrícia de Araujo Abucarma; SHIMAZAKI, Elsa Midori. Produção de texto no $3^{\circ}$ ano do ensino fundamental: revisão e reescrita no desenvolvimento das funções psicológicas superiores. RBEP, Brasília, v. 102, n. 260, p. 263-282, jan./abr. 2021. Seção: Relatos de Experiência.

Professor técnico - autonomia docente-Sistemas Apostilados de Ensino. ORTIZ, Gabriel Santos; DENARDIN, Luciano; SAVI NETO, Pedro. Sistemas Apostilados de Ensino e a autonomia ilusória: reflexões à luz de José Contreras. RBEP, Brasília, v. 102, n. 262, p. 607-625, set./dez. 2021. Seção: Estudos.

Programa Ensino Médio Inovador - análise cognitiva de políticas públicas - ensino médio - políticas educacionais.

FERREIRA, Eliza Bartolozzi; TARTAGLIA, Leonara Margotto; BASTOS, 
Roberta Freire. Políticas inovadoras para o ensino médio no Brasil: um estudo de caso do ProEMI. RBEP, Brasília, v. 102, n. 262, p. 742-763, set./ dez. 2021. Seção: Estudos.

Projeto de letramento - letramentos locais e globais - Pibid.

GESSER, Andressa Regiane. Projetos de letramento e suas contribuições para a ampliação dos conhecimentos locais e globais sobre a diversidade cultural brasileira. RBEP, Brasília, v. 102, n. 261, p. 503-520, maio/ago. 2021. Seção: Relatos de Experiência.

Recepção literária - diáspora africana - relações étnico-raciais. DIAS, Thiago Leandro da Silva; SOUZA, Rogério Santos. Tessitura e subsídios de um produto literário infantojuvenil para o ensino da história e cultura africana e afro-brasileira. RBEP, Brasília, v. 102, n. 261, p. 376397, maio/ago. 2021. Seção: Estudos.

Relações étnico-raciais - diáspora africana - recepção literária. DIAS, Thiago Leandro da Silva; SOUZA, Rogério Santos. Tessitura e subsídios de um produto literário infantojuvenil para o ensino da história e cultura africana e afro-brasileira. RBEP, Brasília, v. 102, n. 261, p. 376397, maio/ago. 2021. Seção: Estudos.

Resenha - educação contra a barbárie - debates em educação.

SILVA JUNIOR, Jonas Alves da. Um livro de combate contra a barbárie na educação brasileira. RBEP, Brasília, v. 102, n. 260, p. 309-314, jan./abr. 2021. Seção: Resenhas.

Retórica - comunicação - John Dewey.

SILVA, Tatiane da; CUNHA, Marcus Vinicius da. Educação, comunicação e imaginação em John Dewey: contribuições teóricas e práticas. RBEP, Brasília, v. 102, n. 262, p. 626-641, set./dez. 2021. Seção: Estudos.

Revisão e reescrita-funções psicológicas superiores - produção de textos. STEVANATO, Patrícia de Araujo Abucarma; SHIMAZAKI, Elsa Midori. Produção de texto no $3^{\circ}$ ano do ensino fundamental: revisão e reescrita no desenvolvimento das funções psicológicas superiores. RBEP, Brasília, v. 102, n. 260, p. 263-282, jan./abr. 2021. Seção: Relatos de Experiência.

Saúde e educação - cultura tradicional - educação no meio rural. ROSA, Walquíria Miranda; GALVÃO, Ana Maria de Oliveira. Práticas de cura, saberes tradicionais e conhecimentos escolares: um estudo sobre uma comunidade rural de Minas Gerais (1940-1970). RBEP, Brasília, v. 102, n. 260, p. 23-42, jan./abr. 2021. Seção: Estudos.

Sistema de cotas - ação afirmativa - impacto social.

LOPES, Ronaldo André; SILVA, Guilherme Henrique Gomes da; FERREIRA, Eric Batista. A Lei de Cotas e o acesso à Universidade Federal de Alfenas 
por estudantes pertencentes a grupos sub-representados. RBEP, Brasília, v. 102, n. 260, p. 148-176, jan./abr. 2021. Seção: Estudos.

Sistema de ensino estadual - avaliação da educação - Distrito Federal - formação de professores.

WELLER, Wivian; SILVA, Cilene Vilarins Cardoso da. Ensino médio público no passado e no presente: visões de docentes de distintas gerações do Distrito Federal. RBEP, Brasília, v. 102, n. 260, p. 63-81, jan./abr. 2021. Seção: Estudos.

Sistemas Apostilados de Ensino - autonomia docente-professor técnico. ORTIZ, Gabriel Santos; DENARDIN, Luciano; SAVI NETO, Pedro. Sistemas Apostilados de Ensino e a autonomia ilusória: reflexões à luz de José Contreras. RBEP, Brasília, v. 102, n. 262, p. 607-625, set./dez. 2021. Seção: Estudos.

Tecnologia social - educação do campo - princípios agroecológicos. DOMINGUES, Sérgio; SANTOS JUNIOR, Cezário Ferreira dos; NUNES, Aline; BONADIMAN, Ariel. Agroecologia e Pedagogia da Alternância: um estudo de caso da Escola Tecnológica de Fraiburgo, Santa Catarina. RBEP, Brasília, v. 102, n. 262, p. 764-786, set./dez. 2021. Seção: Estudos.

Transição para a vida adulta - ensino médio - juventude.

LEBOURG, Elodia Honse; COUTRIM, Rosa Maria da Exaltação; SILVA, Luciano Campos da. Juventude e transição para o ensino médio: desafios e projetos de futuro. RBEP, Brasília, v. 102, n. 260, p. 82-98, jan./abr. 2021. Seção: Estudos.

Transtorno da habilidade motora - educação inclusiva - percepção docente.

MAIA, Samia Darcila Barros; FERREIRA, Lúcio Fernandes; SOUZA, Cleverton José Farias de. Percepção do docente e o Transtorno do Desenvolvimento da Coordenação (TDC): um estudo de revisão integrativa. RBEP, Brasília, v. 102, n. 261, p. 398-414, maio/ago. 2021. Seção: Estudos.

\section{Vivências - ensino técnico - extensão rural - prática social.}

FACCO, Hector dos Santos; DISKA, Nathana Marina; SILVA, Gustavo Pinto da. As vivências como metodologia de ensino da extensão rural: a aproximação entre estudantes e agricultores para a compreensão da realidade social. RBEP, Brasília, v. 102, n. 262, p. 821-838, set./dez. 2021. Seção: Relatos de Experiência. 


\section{ÍNDice DE AUTORES RBEP}

AMÂNCIO, Márcia Helena; CASTIONI, Remi. Anísio Teixeira e o Plano Nacional de Educação de 1962: qualidade social na construção da pessoa humana e da sociedade. RBEP, Brasília, v. 102, n. 262, p. 723-741, set./dez. 2021. Seção: Estudos.

ANDRADE, Sammela Rejane de Jesus; FREITAG, Raquel Meister Ko. Objetivos educacionais e avaliações em larga escala na trajetória da educação superior brasileira: Enem, Enade e a complexidade cognitiva na retenção do fluxo. RBEP, Brasília, v. 102, n. 260, p. 177-204, jan./abr. 2021. Seção: Estudos.

ANDRIOLA, Wagner Bandeira; ARAÚJO, Adriana Castro. Avaliação dos impactos do Programa de Apoio a Planos de Expansão e Reestruturação das Universidades Federais Brasileiras. RBEP, Brasília, v. 102, n. 261, p. 437-464, maio/ago. 2021. Seção: Estudos.

ARAÚJO, Adriana Castro; ANDRIOLA, Wagner Bandeira. Avaliação dos impactos do Programa de Apoio a Planos de Expansão e Reestruturação das Universidades Federais Brasileiras. RBEP, Brasília, v. 102, n. 261, p. 437-464, maio/ago. 2021. Seção: Estudos.

ARAUJO, Ana Paula Sandes; LIBARDI Suzana Santos; GOMES, Carmelita Maria. A colaboração em pesquisa como ferramenta metodológica para formação de professores/as na licenciatura. RBEP, Brasília, v. 102, n. 260, p. 243-262, jan./abr. 2021. Seção: Relatos de Experiência. 
ARAÚJO, Gisele Silva; SEABRA JUNIOR, Manoel Osmar. Elementos fundamentais para o design de jogos digitais com o foco no treino de competências e habilidades de estudantes com transtorno do espectro autista: uma revisão sistemática. RBEP, Brasília, v. 102, n. 260, p. 120-147, jan./abr. 2021. Seção: Estudos.

ARAÚJO, Maria Cristina Pansera de; SCHWINGEL, Tatiane Cristina Possel Greter. Educação em Saúde na escola: conhecimentos, valores e práticas na formação de professores. RBEP, Brasília, v. 102, n. 261, p. 465-485, maio/ ago. 2021. Seção: Estudos.

BARROS, José Batista de; BOULITREAU, Paula Roberta Paschoal; ROSA, Adriana Letícia Torres da; MACEDO, Bárbara Cristina Oliveira. Inclusão e acessibilidade na escola: conhecendo a deficiência visual nas aulas de Língua Portuguesa. RBEP, Brasília, v. 102, n. 261, p. 521-542, maio/ago. 2021. Seção: Relatos de Experiência.

BASTOS, Roberta Freire; FERREIRA, Eliza Bartolozzi; TARTAGLIA, Leonara Margotto. Políticas inovadoras para o ensino médio no Brasil: um estudo de caso do ProEMI. RBEP, Brasília, v. 102, n. 262, p. 742-763, set./ dez. 2021. Seção: Estudos.

BOFF, Eva Teresinha de Oliveira; RECH, Rose Aparecida Colognese. A constituição da identidade docente e suas implicações nas práticas educativas de professores de uma universidade comunitária. RBEP, Brasília, v. 102, n. 262, p. 642-667, set./dez. 2021. Seção: Estudos.

BONADIMAN, Ariel; DOMINGUES, Sérgio; SANTOS JÚNIOR, Cezário Ferreira dos; NUNES, Aline. Agroecologia e Pedagogia da Alternância: um estudo de caso da Escola Tecnológica de Fraiburgo, Santa Catarina. RBEP, Brasília, v. 102, n. 262, p. 764-786, set./dez. 2021. Seção: Estudos.

BOUlitREAU, Paula Roberta Paschoal; BARROS, José Batista de; ROSA, Adriana Letícia Torres da; MACEDO, Bárbara Cristina Oliveira. Inclusão e acessibilidade na escola: conhecendo a deficiência visual nas aulas de Língua Portuguesa. RBEP, Brasília, v. 102, n. 261, p. 521-542, maio/ago. 2021. Seção: Relatos de Experiência.

BRAZ, Paula Paulino; RANGNI, Rosemeire de Araújo. Enriquecimento para um aluno com altas habilidades/superdotação na educação infantil. RBEP, Brasília, v. 102, n. 262, p. 802-820, set./dez. 2021. Seção: Relatos de Experiência.

CACETE, Núria Hanglei; DURÃES, Fabíola Alice dos Anjos; MOURA, Cleberson Henrique de. O estudo do meio como opção metodológica na formação inicial de professores/as de Geografia: relato de experiência nas cidades históricas do Vale do Rio Paraíba do Sul Paulista. RBEP, Brasília, v. 102, n. 261, p. 543-563, maio/ago. 2021. Seção: Relatos de Experiência. 
CASTIONI, Remi; AMÂNCIO, Márcia Helena. Anísio Teixeira e o Plano Nacional de Educação de 1962 - qualidade social na construção da pessoa humana e da sociedade. RBEP, Brasília, v. 102, n. 262, p. 723-741, set./dez. 2021. Seção: Estudos.

COSTA, Anderson Gonçalves; VIDAL, Eloisa Maia. Prêmio Escola Nota Dez no estado do Ceará: concessão, ajustes e responsabilização. RBEP, Brasília, v. 102, n. 261, p. 415-436, maio/ago. 2021. Seção: Estudos.

COUTRIM, Rosa Maria da Exaltação; LEBOURG, Elodia Honse; SILVA, Luciano Campos da. Juventude e transição para o ensino médio: desafios e projetos de futuro. RBEP, Brasília, v. 102, n. 260, p. 82-98, jan./abr. 2021. Seção: Estudos.

CUNHA, Marcus Vinicius da; SILVA, Tatiane da. Educação, comunicação e imaginação em John Dewey: contribuições teóricas e práticas. RBEP, Brasília, v. 102, n. 262, p. 626-641, set./dez. 2021. Seção: Estudos.

DENARDIN, Luciano; ORTIZ, Gabriel Santos; SAVI NETO, Pedro. Sistemas Apostilados de Ensino e a autonomia ilusória: reflexões à luz de José Contreras. RBEP, Brasília, v. 102, n. 262, p. 607-625, set./dez. 2021. Seção: Estudos.

DIAS, Thiago Leandro da Silva; SOUZA, Rogério Santos. Tessitura e subsídios de um produto literário infantojuvenil para o ensino da história e cultura africana e afro-brasileira. RBEP, Brasília, v. 102, n. 261, p. 376397, maio/ago. 2021. Seção: Estudos.

DISKA, Nathana Marina; FACCO, Hector dos Santos; SILVA, Gustavo Pinto da. As vivências como metodologia de ensino da extensão rural: a aproximação entre estudantes e agricultores para a compreensão da realidade social. RBEP, Brasília, v. 102, n. 262, p. 821-838, set./dez. 2021. Seção: Relatos de Experiência.

DOMINGUES, Sérgio; SANTOS JÚNIOR, Cezário Ferreira dos; NUNES, Aline; BONADIMAN, Ariel. Agroecologia e Pedagogia da Alternância: um estudo de caso da Escola Tecnológica de Fraiburgo, Santa Catarina. RBEP, Brasília, v. 102, n. 262, p. 764-786, set./dez. 2021. Seção: Estudos.

DURÃES, Fabíola Alice dos Anjos; CACETE, Núria Hanglei; MOURA, Cleberson Henrique de. O estudo do meio como opção metodológica na formação inicial de professores/as de Geografia: relato de experiência nas cidades históricas do Vale do Rio Paraíba do Sul Paulista. RBEP, Brasília, v. 102, n. 261, p. 543-563, maio/ago. 2021. Seção: Relatos de Experiência.

ESQUINSANI, Rosimar Serena Siqueira; SILVEIRA, Carmem Lúcia Albrecht; LAUER, Munir José. O sentido do brincar e do jogar na infância humana como fundamentos para a construção da democracia social. RBEP, Brasília, v. 102, n. 262, p. 787-801, set./dez. 2021. Seção: Estudos. 
FABRIS, Elí Terezinha Henn; WESCHENFELDER, Viviane Inês; OLIVEIRA, Joelma Fernandes de. Docência e relações interculturais na fronteira Brasil-Venezuela. RBEP, Brasília, v. 102, n. 262, p. 668-688, set./dez. 2021. Seção: Estudos.

FACCO, Hector dos Santos; DISKA, Nathana Marina; SILVA, Gustavo Pinto da. As vivências como metodologia de ensino da extensão rural: a aproximação entre estudantes e agricultores para a compreensão da realidade social. RBEP, Brasília, v. 102, n. 262, p. 821-838, set./dez. 2021. Seção: Relatos de Experiência.

FELICIO, Cinthia Maria; MATOS, Jainer Diogo Vieira; NOLL, Matias; FERREIRA, Júlio César. Prática educativa crítico-reflexiva em Gestão Ambiental e Responsabilidade Social: um relato de experiência. RBEP, Brasília, v. 102, n. 261, p. 564-582, maio/ago. 2021. Seção: Relatos de Experiência.

FERREIRA, Eliza Bartolozzi; TARTAGLIA, Leonara Margotto; BASTOS, Roberta Freire. Políticas inovadoras para o ensino médio no Brasil: um estudo de caso do ProEMI. RBEP, Brasília, v. 102, n. 262, p. 742-763, set./ dez. 2021. Seção: Estudos.

FERREIRA, Eric Batista; LOPES, Ronaldo André; SILVA, Guilherme Henrique Gomes da. A Lei de Cotas e o acesso à Universidade Federal de Alfenas por estudantes pertencentes a grupos sub-representados. RBEP, Brasília, v. 102, n. 260, p. 148-176, jan./abr. 2021. Seção: Estudos.

FERREIRA, Júlio César; MATOS, Jainer Diogo Vieira; NOLL, Matias; FELICIO, Cinthia Maria. Prática educativa crítico-reflexiva em Gestão Ambiental e Responsabilidade Social: um relato de experiência. RBEP, Brasília, v. 102, n. 261, p. 564-582, maio/ago. 2021. Seção: Relatos de Experiência.

FERREIRA, Lúcio Fernandes; MAIA, Samia Darcila Barros; SOUZA, Cleverton José Farias de. Percepção do docente e o Transtorno do Desenvolvimento da Coordenação (TDC): um estudo de revisão integrativa. RBEP, Brasília, v. 102, n. 261, p. 398-414, maio/ago. 2021. Seção: Estudos.

FRANCO, Ana Beatriz Momesso; VILARONGA, Carla Ariela Rios; SILVA, Michele Oliveira da; RIOS, Gabriela Alias. Inclusão escolar e atuação dos Núcleos de Apoio às Pessoas com Necessidades Educacionais Específicas no Instituto Federal de São Paulo. RBEP, Brasília, v. 102, n. 260, p. 283-308, jan./abr. 2021. Seção: Relatos de Experiência.

FREITAG, Raquel Meister Ko; ANDRADE, Sammela Rejane de Jesus. Objetivos educacionais e avaliações em larga escala na trajetória da educação superior brasileira: Enem, Enade e a complexidade cognitiva na retenção do fluxo. RBEP, Brasília, v. 102, n. 260, p. 177-204, jan./abr. 2021. Seção: Estudos. 
GAlVÃO, Ana Maria de Oliveira; ROSA, Walquíria Miranda. Práticas de cura, saberes tradicionais e conhecimentos escolares: um estudo sobre uma comunidade rural de Minas Gerais (1940-1970). RBEP, Brasília, v. 102, n. 260, p. 23-42, jan./abr. 2021. Seção: Estudos.

GESSER, Andressa Regiane. Projetos de letramento e suas contribuições para a ampliação dos conhecimentos locais e globais sobre a diversidade cultural brasileira. RBEP, Brasília, v. 102, n. 261, p. 503-520, maio/ago. 2021. Seção: Relatos de Experiência.

GIORDAN, Miriane Zanetti; SARTI, Flavia Medeiros. Autoconfrontação cruzada em grupo focal: recurso metodológico para pesquisas em Educação. RBEP, Brasília, v. 102, n. 262, p. 707-722, set./dez. 2021. Seção: Estudos.

GOMES, Carmelita Maria; LIBARDI Suzana Santos; ARAUJO, Ana Paula Sandes. A colaboração em pesquisa como ferramenta metodológica para formação de professores/as na licenciatura. RBEP, Brasília, v. 102, n. 260, p. 243-262, jan./abr. 2021. Seção: Relatos de Experiência.

LAUER, Munir José; SILVEIRA, Carmem Lúcia Albrecht; ESQUINSANI, Rosimar Serena Siqueira. O sentido do brincar e do jogar na infância humana como fundamentos para a construção da democracia social. RBEP, Brasília, v. 102, n. 262, p. 787-801, set./dez. 2021. Seção: Estudos.

LEBOURG, Elodia Honse; COUTRIM, Rosa Maria da Exaltação; SILVA, Luciano Campos da. Juventude e transição para o ensino médio: desafios e projetos de futuro. RBEP, Brasília, v. 102, n. 260, p. 82-98, jan./abr. 2021. Seção: Estudos.

LIBARDI Suzana Santos; GOMES, Carmelita Maria; ARAUJO, Ana Paula Sandes. A colaboração em pesquisa como ferramenta metodológica para formação de professores/as na licenciatura. RBEP, Brasília, v. 102, n. 260, p. 243-262, jan./abr. 2021. Seção: Relatos de Experiência.

LIMA, Izauriana Borges; SELVA, Ana Coêlho Vieira. Interpretação de gráficos de barras na educação de jovens e adultos. RBEP, Brasília, v. 102, n. 260, p. 218-242, jan./abr. 2021. Seção: Estudos.

LOPES, Ronaldo André; SILVA, Guilherme Henrique Gomes da; FERREIRA, Eric Batista. A Lei de Cotas e o acesso à Universidade Federal de Alfenas por estudantes pertencentes a grupos sub-representados. RBEP, Brasília, v. 102, n. 260, p. 148-176, jan./abr. 2021. Seção: Estudos.

LOPES, Suzana Gomes; SILVA, Alexandre Leite dos Santos; SOUSA, Caroline Lucena de. Vivências e memórias entre a Escola Monsenhor Lopes e a Comunidade Forte. RBEP, Brasília, v. 102, n. 260, p. 43-62, jan./abr. 2021. Seção: Estudos. 
MACEDO, Bárbara Cristina Oliveira; BOULITREAU, Paula Roberta Paschoal; BARROS, José Batista de; ROSA, Adriana Letícia Torres da. Inclusão e acessibilidade na escola: conhecendo a deficiência visual nas aulas de Língua Portuguesa. RBEP, Brasília, v. 102, n. 261, p. 521-542, maio/ago. 2021. Seção: Relatos de Experiência.

MAGALHÃES JÚNIOR, Carlos Alberto de Oliveira; TRIANI, Felipe da Silva; SOUZA, Anna Carolina Carvalho de; TELLES, Silvio de Cassio Costa. Representações sociais de graduandos em Educação Física sobre o meio ambiente e a relação homem, esporte e natureza. RBEP, Brasília, v. 102, n. 260, p. 205-217, jan./abr. 2021. Seção: Estudos.

MAIA, Samia Darcila Barros; FERREIRA, Lúcio Fernandes; SOUZA, Cleverton José Farias de. Percepção do docente e o Transtorno do Desenvolvimento da Coordenação (TDC): um estudo de revisão integrativa. RBEP, Brasília, v. 102, n. 261, p. 398-414, maio/ago. 2021. Seção: Estudos.

MARTINS, Evellyn Priscila Nunes; TEIXEIRA JÚNIOR, José Gonçalves. Análise das contribuições da disciplina de Didática Geral para a formação de professores de Química. RBEP, Brasília, v. 102, n. 261, p. 486-502, maio/ ago. 2021. Seção: Estudos.

MATOS, Jainer Diogo Vieira; NOLL, Matias; FELICIO, Cinthia Maria; FERREIRA, Júlio César. Prática educativa crítico-reflexiva em Gestão Ambiental e Responsabilidade Social: um relato de experiência. RBEP, Brasília, v. 102, n. 261, p. 564-582, maio/ago. 2021. Seção: Relatos de Experiência.

MATOS, Maria Almerinda de Souza; SANTOS, João Otacilio Libardoni dos; SADIM, Geyse Pattrizzia Teixeira; SCHMIDT, Carlo. O atendimento educacional especializado para os educandos com autismo na rede municipal de Manaus-AM. RBEP, Brasília, v. 102, n. 260, p. 99-119, jan./abr. 2021. Seção: Estudos.

MOURA, Cleberson Henrique de; CACETE, Núria Hanglei; DURÃES, Fabíola Alice dos Anjos. O estudo do meio como opção metodológica na formação inicial de professores/as de Geografia: relato de experiência nas cidades históricas do Vale do Rio Paraíba do Sul Paulista. RBEP, Brasília, v. 102, n. 261, p. 543-563, maio/ago. 2021. Seção: Relatos de Experiência.

NOLL, Matias; MATOS, Jainer Diogo Vieira; FELICIO, Cinthia Maria; FERREIRA, Júlio César. Prática educativa crítico-reflexiva em Gestão Ambiental e Responsabilidade Social: um relato de experiência. RBEP, Brasília, v. 102, n. 261, p. 564-582, maio/ago. 2021. Seção: Relatos de Experiência. 
NUNES, Aline; DOMINGUES, Sérgio; SANTOS JÚNIOR, Cezário Ferreira dos; BONADIMAN, Ariel. Agroecologia e Pedagogia da Alternância: um estudo de caso da Escola Tecnológica de Fraiburgo, Santa Catarina. RBEP, Brasília, v. 102, n. 262, p. 764-786, set./dez. 2021. Seção: Estudos.

OLIVEIRA, Joelma Fernandes de; WESCHENFELDER, Viviane Inês; FABRIS, Elí Terezinha Henn. Docência e relações interculturais na fronteira BrasilVenezuela. RBEP, Brasília, v. 102, n. 262, p. 668-688, set./dez. 2021. Seção: Estudos.

ORTIZ, Gabriel Santos; DENARDIN, Luciano; SAVI NETO, Pedro. Sistemas Apostilados de Ensino e a autonomia ilusória: reflexões à luz de José Contreras. RBEP, Brasília, v. 102, n. 262, p. 607-625, set./dez. 2021. Seção: Estudos.

QUEIROZ, Paulo Pires de; SANTOS, Rosane Barreto Ramos dos. A complexa relação humana no espaço escolar: o que indisciplina, currículo e cultura têm a nos revelar? RBEP, Brasília, v. 102, n. 261, p. 339-356, maio/ago. 2021. Seção: Estudos.

RANGNI, Rosemeire de Araújo; BRAZ, Paula Paulino. Enriquecimento para um aluno com altas habilidades/superdotação na educação infantil. RBEP, Brasília, v. 102, n. 262, p. 802-820, set./dez. 2021. Seção: Relatos de Experiência.

RECH, Rose Aparecida Colognese; BOFF, Eva Teresinha de Oliveira. A constituição da identidade docente e suas implicações nas práticas educativas de professores de uma universidade comunitária. RBEP, Brasília, v. 102, n. 262, p. 642-667, set./dez. 2021. Seção: Estudos.

RIOS, Gabriela Alias; VILARONGA, Carla Ariela Rios; SILVA, Michele Oliveira da; FRANCO, Ana Beatriz Momesso. Inclusão escolar e atuação dos Núcleos de Apoio às Pessoas com Necessidades Educacionais Específicas no Instituto Federal de São Paulo. RBEP, Brasília, v. 102, n. 260, p. 283-308, jan./abr. 2021. Seção: Relatos de Experiência.

ROSA, Adriana Letícia Torres da; BOULITREAU, Paula Roberta Paschoal; BARROS, José Batista de; MACEDO, Bárbara Cristina Oliveira. Inclusão e acessibilidade na escola: conhecendo a deficiência visual nas aulas de Língua Portuguesa. RBEP, Brasília, v. 102, n. 261, p. 521-542, maio/ago. 2021. Seção: Relatos de Experiência.

ROSA, Walquíria Miranda; GALVÃO, Ana Maria de Oliveira. Práticas de cura, saberes tradicionais e conhecimentos escolares: um estudo sobre uma comunidade rural de Minas Gerais (1940-1970). RBEP, Brasília, v. 102, n. 260, p. 23-42, jan./abr. 2021. Seção: Estudos. 
SADIM, Geyse Pattrizzia Teixeira; SANTOS, João Otacilio Libardoni dos; SCHMIDT, Carlo; MATOS, Maria Almerinda de Souza. O atendimento educacional especializado para os educandos com autismo na rede municipal de Manaus-AM. RBEP, Brasília, v. 102, n. 260, p. 99-119, jan./abr. 2021. Seção: Estudos.

SANTOS JÚNIOR, Cezário Ferreira dos; DOMINGUES, Sérgio; NUNES, Aline; BONADIMAN, Ariel. Agroecologia e Pedagogia da Alternância: um estudo de caso da Escola Tecnológica de Fraiburgo, Santa Catarina. RBEP, Brasília, v. 102, n. 262, p. 764-786, set./dez. 2021. Seção: Estudos.

SANTOS, João Otacilio Libardoni dos; SADIM, Geyse Pattrizzia Teixeira; SCHMIDT, Carlo; MATOS, Maria Almerinda de Souza. O atendimento educacional especializado para os educandos com autismo na rede municipal de Manaus-AM. RBEP, Brasília, v. 102, n. 260, p. 99-119, jan./abr. 2021. Seção: Estudos.

SANTOS, Rosane Barreto Ramos dos; QUEIROZ, Paulo Pires de. A complexa relação humana no espaço escolar: o que indisciplina, currículo e cultura têm a nos revelar? RBEP, Brasília, v. 102, n. 261, p. 339-356, maio/ago. 2021. Seção: Estudos.

SARTI, Flavia Medeiros; GIORDAN, Miriane Zanetti. Autoconfrontação cruzada em grupo focal: recurso metodológico para pesquisas em Educação. RBEP, Brasília, v. 102, n. 262, p. 707-722, set./dez. 2021. Seção: Estudos.

SAVI NETO, Pedro; ORTIZ, Gabriel Santos; DENARDIN, Luciano. Sistemas Apostilados de Ensino e a autonomia ilusória: reflexões à luz de José Contreras. RBEP, Brasília, v. 102, n. 262, p. 607-625, set./dez. 2021. Seção: Estudos.

SCHMIDT, Carlo; SANTOS, João Otacilio Libardoni dos; SADIM, Geyse Pattrizzia Teixeira; MATOS, Maria Almerinda de Souza. O atendimento educacional especializado para os educandos com autismo na rede municipal de Manaus-AM. RBEP, Brasília, v. 102, n. 260, p. 99-119, jan./abr. 2021. Seção: Estudos.

SCHWINGEL, Tatiane Cristina Possel Greter; ARAÚJO, Maria Cristina Pansera de. Educação em Saúde na escola: conhecimentos, valores e práticas na formação de professores. RBEP, Brasília, v. 102, n. 261, p. 465-485, maio/ago. 2021. Seção: Estudos.

SEABRA JUNIOR, Manoel Osmar; ARAÚJO, Gisele Silva. Elementos fundamentais para o design de jogos digitais com o foco no treino de competências e habilidades de estudantes com transtorno do espectro autista: uma revisão sistemática. RBEP, Brasília, v. 102, n. 260, p. 120-147, jan./abr. 2021. Seção: Estudos. 
SELVA, Ana Coêlho Vieira; LIMA, Izauriana Borges. Interpretação de gráficos de barras na educação de jovens e adultos. RBEP, Brasília, v. 102, n. 260, p. 218-242, jan./abr. 2021. Seção: Estudos.

SHIMAZAKI, Elsa Midori; STEVANATO, Patrícia de Araujo Abucarma. Produção de texto no $3^{\circ}$ ano do ensino fundamental: revisão e reescrita no desenvolvimento das funções psicológicas superiores. RBEP, Brasília, v. 102, n. 260, p. 263-282, jan./abr. 2021. Seção: Relatos de Experiência.

SILVA, Alexandre Leite dos Santos; LOPES, Suzana Gomes; SOUSA, Caroline Lucena de. Vivências e memórias entre a Escola Monsenhor Lopes e a Comunidade Forte. RBEP, Brasília, v. 102, n. 260, p. 43-62, jan./abr. 2021. Seção: Estudos.

SILVA, Cilene Vilarins Cardoso da; WELLER, Wivian. Ensino médio público no passado e no presente: visões de docentes de distintas gerações do Distrito Federal. RBEP, Brasília, v. 102, n. 260, p. 63-81, jan./abr. 2021. Seção: Estudos.

SILVA, Guilherme Henrique Gomes da; LOPES, Ronaldo André; FERREIRA, Eric Batista. A Lei de Cotas e o acesso à Universidade Federal de Alfenas por estudantes pertencentes a grupos sub-representados. RBEP, Brasília, v. 102, n. 260, p. 148-176, jan./abr. 2021. Seção: Estudos.

SILVA, Gustavo Pinto da; FACCO, Hector dos Santos; DISKA, Nathana Marina. As vivências como metodologia de ensino da extensão rural: a aproximação entre estudantes e agricultores para a compreensão da realidade social. RBEP, Brasília, v. 102, n. 262, p. 821-838, set./dez. 2021. Seção: Relatos de Experiência.

SILVA, Luciano Campos da; LEBOURG, Elodia Honse; COUTRIM, Rosa Maria da Exaltação. Juventude e transição para o ensino médio: desafios e projetos de futuro. RBEP, Brasília, v. 102, n. 260, p. 82-98, jan./abr. 2021. Seção: Estudos.

SILVA, Michele Oliveira da; VILARONGA, Carla Ariela Rios; FRANCO, Ana Beatriz Momesso; RIOS, Gabriela Alias. Inclusão escolar e atuação dos Núcleos de Apoio às Pessoas com Necessidades Educacionais Específicas no Instituto Federal de São Paulo. RBEP, Brasília, v. 102, n. 260, p. 283-308, jan./abr. 2021. Seção: Relatos de Experiência.

SILVA, Tatiane da; CUNHA, Marcus Vinicius da. Educação, comunicação e imaginação em John Dewey: contribuições teóricas e práticas. RBEP, Brasília, v. 102, n. 262, p. 626-641, set./dez. 2021. Seção: Estudos.

SILVA JUNIOR, Jonas Alves da. Um livro de combate contra a barbárie na educação brasileira. RBEP, Brasília, v. 102, n. 260, p. 309-314, jan./abr. 2021. Seção: Resenhas. 
SILVEIRA, Carmem Lúcia Albrecht; LAUER, Munir José; ESQUINSANI, Rosimar Serena Siqueira. O sentido do brincar e do jogar na infância humana como fundamentos para a construção da democracia social. RBEP, Brasília, v. 102, n. 262, p. 787-801, set./dez. 2021. Seção: Estudos.

SOUSA, Caroline Lucena de; LOPES, Suzana Gomes; SILVA, Alexandre Leite dos Santos. Vivências e memórias entre a Escola Monsenhor Lopes e a Comunidade Forte. RBEP, Brasília, v. 102, n. 260, p. 43-62, jan./abr. 2021. Seção: Estudos.

SOUZA, Anna Carolina Carvalho de; TRIANI, Felipe da Silva; MAGALHÃES JÚNIOR, Carlos Alberto de Oliveira; TELLES, Silvio de Cassio Costa. Representações sociais de graduandos em Educação Física sobre o meio ambiente e a relação homem, esporte e natureza. RBEP, Brasília, v. 102, n. 260, p. 205-217, jan./abr. 2021. Seção: Estudos.

SOUZA, Cleverton José Farias de; MAIA, Samia Darcila Barros; FERREIRA, Lúcio Fernandes. Percepção do docente e o Transtorno do Desenvolvimento da Coordenação (TDC): um estudo de revisão integrativa. RBEP, Brasília, v. 102, n. 261, p. 398-414, maio/ago. 2021. Seção: Estudos.

SOUZA, Mariana Aparecida Serejo de. O lugar da educação não escolar nos currículos de Pedagogia. RBEP, Brasília, v. 102, n. 262, p. 689-706, set./ dez. 2021. Seção: Estudos.

SOUZA, Rogério Santos; DIAS, Thiago Leandro da Silva. Tessitura e subsídios de um produto literário infantojuvenil para o ensino da história e cultura africana e afro-brasileira. RBEP, Brasília, v. 102, n. 261, p. 376397, maio/ago. 2021. Seção: Estudos.

SteVAnAto, Patrícia de Araujo Abucarma; SHIMAZAKI, Elsa Midori. Produção de texto no $3^{\circ}$ ano do ensino fundamental: revisão e reescrita no desenvolvimento das funções psicológicas superiores. RBEP, Brasília, v. 102, n. 260, p. 263-282, jan./abr. 2021. Seção: Relatos de Experiência.

TARTAGLIA, Leonara Margotto; FERREIRA, Eliza Bartolozzi; BASTOS, Roberta Freire. Políticas inovadoras para o ensino médio no Brasil: um estudo de caso do ProEMI. RBEP, Brasília, v. 102, n. 262, p. 742-763, set./ dez. 2021. Seção: Estudos.

TEIXEIRA JÚNIOR, José Gonçalves; MARTINS, Evellyn Priscila Nunes. Análise das contribuições da disciplina de Didática Geral para a formação de professores de Química. RBEP, Brasília, v. 102, n. 261, p. 486-502, maio/ ago. 2021. Seção: Estudos. 
TELLES, Silvio de Cassio Costa; TRIANI, Felipe da Silva; SOUZA, Anna Carolina Carvalho de; MAGALHÃES JÚNIOR, Carlos Alberto de Oliveira. Representações sociais de graduandos em Educação Física sobre o meio ambiente e a relação homem, esporte e natureza. RBEP, Brasília, v. 102, n. 260, p. 205-217, jan./abr. 2021. Seção: Estudos.

TRIANI, Felipe da Silva; SOUZA, Anna Carolina Carvalho de; MAGALHÃES JÚNIOR, Carlos Alberto de Oliveira; TELLES, Silvio de Cassio Costa. Representações sociais de graduandos em Educação Física sobre o meio ambiente e a relação homem, esporte e natureza. RBEP, Brasília, v. 102, n. 260, p. 205-217, jan./abr. 2021. Seção: Estudos.

VIDAL, Eloisa Maia; COSTA, Anderson Gonçalves. Prêmio Escola Nota Dez no estado do Ceará: concessão, ajustes e responsabilização. RBEP, Brasília, v. 102, n. 261, p. 415-436, maio/ago. 2021. Seção: Estudos.

VILARONGA, Carla Ariela Rios; SILVA, Michele Oliveira da; FRANCO, Ana Beatriz Momesso; RIOS, Gabriela Alias. Inclusão escolar e atuação dos Núcleos de Apoio às Pessoas com Necessidades Educacionais Específicas no Instituto Federal de São Paulo. RBEP, Brasília, v. 102, n. 260, p. 283-308, jan./abr. 2021. Seção: Relatos de Experiência.

WELLER, Wivian; SILVA, Cilene Vilarins Cardoso da. Ensino médio público no passado e no presente: visões de docentes de distintas gerações do Distrito Federal. RBEP, Brasília, v. 102, n. 260, p. 63-81, jan./abr. 2021. Seção: Estudos.

WESCHENFELDER, Viviane Inês; OLIVEIRA, Joelma Fernandes de; FABRIS, Elí Terezinha Henn. Docência e relações interculturais na fronteira BrasilVenezuela. RBEP, Brasília, v. 102, n. 262, p. 668-688, set./dez. 2021. Seção: Estudos. 



\section{índice de títulos RBEP}

Agroecologia e Pedagogia da Alternância: um estudo de caso da Escola Tecnológica de Fraiburgo, Santa Catarina.

DOMINGUES, Sérgio; SANTOS JÚNIOR, Cezário Ferreira dos; NUNES, Aline; BONADIMAN, Ariel. Agroecologia e Pedagogia da Alternância: um estudo de caso da Escola Tecnológica de Fraiburgo, Santa Catarina. RBEP, Brasília, v. 102, n. 262, p. 764-786, set./dez. 2021. Seção: Estudos.

Análise das contribuições da disciplina de Didática Geral para a formação de professores de Química.

MARTINS, Evellyn Priscila Nunes; TEIXEIRA JÚNIOR, José Gonçalves. Análise das contribuições da disciplina de Didática Geral para a formação de professores de Química. RBEP, Brasília, v. 102, n. 261, p. 486-502, maio/ ago. 2021. Seção: Estudos.

Anísio Teixeira e o Plano Nacional de Educação de 1962 - qualidade social na construção da pessoa humana e da sociedade.

AMÂNCIO, Márcia Helena; CASTIONI, Remi. Anísio Teixeira e o Plano Nacional de Educação de 1962 - qualidade social na construção da pessoa humana e da sociedade. RBEP, Brasília, v. 102, n. 262, p. 723-741, set./dez. 2021. Seção: Estudos.

Atendimento educacional especializado para os educandos com autismo na rede municipal de Manaus-AM, 0.

SANTOS, João Otacilio Libardoni dos; SADIM, Geyse Pattrizzia Teixeira; SCHMIDT, Carlo; MATOS, Maria Almerinda de Souza. O atendimento educacional especializado para os educandos com autismo na rede municipal de Manaus-AM. RBEP, Brasília, v. 102, n. 260, p. 99-119, jan./abr. 2021. Seção: Estudos. 
Autoconfrontação cruzada em grupo focal: recurso metodológico para pesquisas em Educação.

GIORDAN, Miriane Zanetti; SARTI, Flavia Medeiros. Autoconfrontação cruzada em grupo focal: recurso metodológico para pesquisas em Educação. RBEP, Brasília, v. 102, n. 262, p. 707-722, set./dez. 2021. Seção: Estudos.

Avaliação dos impactos do Programa de Apoio a Planos de Expansão e Reestruturação das Universidades Federais Brasileiras.

ANDRIOLA, Wagner Bandeira; ARAÚJO, Adriana Castro. Avaliação dos impactos do Programa de Apoio a Planos de Expansão e Reestruturação das Universidades Federais Brasileiras. RBEP, Brasília, v. 102, n. 261, p. 437-464, maio/ago. 2021. Seção: Estudos.

colaboração em pesquisa como ferramenta metodológica para formação de professores/as na licenciatura, A.

LIBARDI Suzana Santos; GOMES, Carmelita Maria; ARAUJO, Ana Paula Sandes. A colaboração em pesquisa como ferramenta metodológica para formação de professores/as na licenciatura. RBEP, Brasília, v. 102, n. 260, p. 243-262, jan./abr. 2021. Seção: Relatos de Experiência.

complexa relação humana no espaço escolar: o que indisciplina, currículo e cultura têm a nos revelar?, A.

SANTOS, Rosane Barreto Ramos dos; QUEIROZ, Paulo Pires de. A complexa relação humana no espaço escolar: o que indisciplina, currículo e cultura têm a nos revelar? RBEP, Brasília, v. 102, n. 261, p. 339-356, maio/ago. 2021. Seção: Estudos.

constituição da identidade docente e suas implicações nas práticas educativas de professores de uma universidade comunitária, A.

RECH, Rose Aparecida Colognese; BOFF, Eva Teresinha de Oliveira. A constituição da identidade docente e suas implicações nas práticas educativas de professores de uma universidade comunitária. RBEP, Brasília, v. 102, n. 262, p. 642-667, set./dez. 2021. Seção: Estudos.

Docência e relações interculturais na fronteira Brasil-Venezuela. WESCHENFELDER, Viviane Inês; OLIVEIRA, Joelma Fernandes de; FABRIS, Elí Terezinha Henn. Docência e relações interculturais na fronteira BrasilVenezuela. RBEP, Brasília, v. 102, n. 262, p. 668-688, set./dez. 2021. Seção: Estudos.

Educação em Saúde na escola: conhecimentos, valores e práticas na formação de professores.

SCHWINGEL, Tatiane Cristina Possel Greter; ARAÚJO, Maria Cristina Pansera de. Educação em Saúde na escola: conhecimentos, valores e práticas na formação de professores. RBEP, Brasília, v. 102, n. 261, p. 465-485, maio/ago. 2021. Seção: Estudos. 
Educação, comunicação e imaginação em John Dewey: contribuições teóricas e práticas.

SILVA, Tatiane da; CUNHA, Marcus Vinicius da. Educação, comunicação e imaginação em John Dewey: contribuições teóricas e práticas. RBEP, Brasília, v. 102, n. 262, p. 626-641, set./dez. 2021. Seção: Estudos.

Elementos fundamentais para o design de jogos digitais com o foco no treino de competências e habilidades de estudantes com transtorno do espectro autista: uma revisão sistemática.

ARAUJO, Gisele Silva; SEABRA JUNIOR, Manoel Osmar. Elementos fundamentais para o design de jogos digitais com o foco no treino de competências e habilidades de estudantes com transtorno do espectro autista: uma revisão sistemática. RBEP, Brasília, v. 102, n. 260, p. 120-147, jan./abr. 2021. Seção: Estudos.

Enriquecimento para um aluno com altas habilidades/superdotação na educação infantil.

BRAZ, Paula Paulino; RANGNI, Rosemeire de Araújo. Enriquecimento para um aluno com altas habilidades/superdotação na educação infantil. RBEP, Brasília, v. 102, n. 262, p. 802-820, set./dez. 2021. Seção: Relatos de Experiência.

Ensino médio público no passado e no presente: visões de docentes de distintas gerações do Distrito Federal.

WELLER, Wivian; SILVA, Cilene Vilarins Cardoso da. Ensino médio público no passado e no presente: visões de docentes de distintas gerações do Distrito Federal. RBEP, Brasília, v. 102, n. 260, p. 63-81, jan./abr. 2021. Seção: Estudos.

estudo do meio como opção metodológica na formação inicial de professores/as de Geografia: relato de experiência nas cidades históricas do Vale do Rio Paraíba do Sul Paulista, O.

CACETE, Núria Hanglei; DURÃES, Fabíola Alice dos Anjos; MOURA, Cleberson Henrique de. O estudo do meio como opção metodológica na formação inicial de professores/as de Geografia: relato de experiência nas cidades históricas do Vale do Rio Paraíba do Sul Paulista. RBEP, Brasília, v. 102, n. 261, p. 543-563, maio/ago. 2021. Seção: Relatos de Experiência.

Inclusão e acessibilidade na escola: conhecendo a deficiência visual nas aulas de Língua Portuguesa.

BOULITREAU, Paula Roberta Paschoal; BARROS, José Batista de; ROSA, Adriana Letícia Torres da; MACEDO, Bárbara Cristina Oliveira. Inclusão e acessibilidade na escola: conhecendo a deficiência visual nas aulas de Língua Portuguesa. RBEP, Brasília, v. 102, n. 261, p. 521-542, maio/ago. 2021. Seção: Relatos de Experiência. 
Inclusão escolar e atuação dos Núcleos de Apoio às Pessoas com Necessidades Educacionais Específicas no Instituto Federal de São Paulo. VILARONGA, Carla Ariela Rios; SILVA, Michele Oliveira da; FRANCO, Ana Beatriz Momesso; RIOS, Gabriela Alias. Inclusão escolar e atuação dos Núcleos de Apoio às Pessoas com Necessidades Educacionais Específicas no Instituto Federal de São Paulo. RBEP, Brasília, v. 102, n. 260, p. 283-308, jan./abr. 2021. Seção: Relatos de Experiência.

Interpretação de gráficos de barras na educação de jovens e adultos. LIMA, Izauriana Borges; SELVA, Ana Coêlho Vieira. Interpretação de gráficos de barras na educação de jovens e adultos. RBEP, Brasília, v. 102, n. 260, p. 218-242, jan./abr. 2021. Seção: Estudos.

Juventude e transição para o ensino médio: desafios e projetos de futuro. LEBOURG, Elodia Honse; COUTRIM, Rosa Maria da Exaltação; SILVA, Luciano Campos da. Juventude e transição para o ensino médio: desafios e projetos de futuro. RBEP, Brasília, v. 102, n. 260, p. 82-98, jan./abr. 2021. Seção: Estudos.

Lei de Cotas e o acesso à Universidade Federal de Alfenas por estudantes pertencentes a grupos sub-representados, A.

LOPES, Ronaldo André; SILVA, Guilherme Henrique Gomes da; FERREIRA, Eric Batista. A Lei de Cotas e o acesso à Universidade Federal de Alfenas por estudantes pertencentes a grupos sub-representados. RBEP, Brasília, v. 102, n. 260, p. 148-176, jan./abr. 2021. Seção: Estudos.

livro de combate contra a barbárie na educação brasileira, Um.

SILVA JUNIOR, Jonas Alves da. Um livro de combate contra a barbárie na educação brasileira. RBEP, Brasília, v. 102, n. 260, p. 309-314, jan./abr. 2021. Seção: Resenhas.

lugar da educação não escolar nos currículos de Pedagogia, 0 .

SOUZA, Mariana Aparecida Serejo de. O lugar da educação não escolar nos currículos de Pedagogia. RBEP, Brasília, v. 102, n. 262, p. 689-706, set./ dez. 2021. Seção: Estudos.

Objetivos educacionais e avaliações em larga escala na trajetória da educação superior brasileira: Enem, Enade e a complexidade cognitiva na retenção do fluxo.

ANDRADE, Sammela Rejane de Jesus; FREITAG, Raquel Meister Ko. Objetivos educacionais e avaliações em larga escala na trajetória da educação superior brasileira: Enem, Enade e a complexidade cognitiva na retenção do fluxo. RBEP, Brasília, v. 102, n. 260, p. 177-204, jan./abr. 2021. Seção: Estudos. 
Percepção do docente e o Transtorno do Desenvolvimento da Coordenação (TDC): um estudo de revisão integrativa.

MAIA, Samia Darcila Barros; FERREIRA, Lúcio Fernandes; SOUZA, Cleverton José Farias de. Percepção do docente e o Transtorno do Desenvolvimento da Coordenação (TDC): um estudo de revisão integrativa. RBEP, Brasília, v. 102, n. 261, p. 398-414, maio/ago. 2021. Seção: Estudos.

Políticas inovadoras para o ensino médio no Brasil: um estudo de caso do ProEMI.

FERREIRA, Eliza Bartolozzi; TARTAGLIA, Leonara Margotto; BASTOS, Roberta Freire. Políticas inovadoras para o ensino médio no Brasil: um estudo de caso do ProEMI. RBEP, Brasília, v. 102, n. 262, p. 742-763, set./ dez. 2021. Seção: Estudos.

Prática educativa crítico-reflexiva em Gestão Ambiental e Responsabilidade Social: um relato de experiência.

MATOS, Jainer Diogo Vieira; NOLL, Matias; FELICIO, Cinthia Maria; FERREIRA, Júlio César. Prática educativa crítico-reflexiva em Gestão Ambiental e Responsabilidade Social: um relato de experiência. RBEP, Brasília, v. 102, n. 261, p. 564-582, maio/ago. 2021. Seção: Relatos de Experiência.

Práticas de cura, saberes tradicionais e conhecimentos escolares: um estudo sobre uma comunidade rural de Minas Gerais (1940-1970). ROSA, Walquíria Miranda; GALVÃO, Ana Maria de Oliveira. Práticas de cura, saberes tradicionais e conhecimentos escolares: um estudo sobre uma comunidade rural de Minas Gerais (1940-1970). RBEP, Brasília, v. 102, n. 260, p. 23-42, jan./abr. 2021. Seção: Estudos.

Prêmio Escola Nota Dez no estado do Ceará: concessão, ajustes e responsabilização.

COSTA, Anderson Gonçalves; VIDAL, Eloisa Maia. Prêmio Escola Nota Dez no estado do Ceará: concessão, ajustes e responsabilização. RBEP, Brasília, v. 102, n. 261, p. 415-436, maio/ago. 2021. Seção: Estudos.

Produção de texto no $3^{\circ}$ ano do ensino fundamental: revisão e reescrita no desenvolvimento das funções psicológicas superiores.

STEVANATO, Patrícia de Araujo Abucarma; SHIMAZAKI, Elsa Midori. Produção de texto no $3^{\circ}$ ano do ensino fundamental: revisão e reescrita no desenvolvimento das funções psicológicas superiores. RBEP, Brasília, v. 102, n. 260, p. 263-282, jan./abr. 2021. Seção: Relatos de Experiência.

Projetos de letramento e suas contribuições para a ampliação dos conhecimentos locais e globais sobre a diversidade cultural brasileira. GESSER, Andressa Regiane. Projetos de letramento e suas contribuições para a ampliação dos conhecimentos locais e globais sobre a diversidade cultural brasileira. RBEP, Brasília, v. 102, n. 261, p. 503-520, maio/ago. 2021. Seção: Relatos de Experiência. 
Representações sociais de graduandos em Educação Física sobre o meio ambiente e a relação homem, esporte e natureza.

TRIANI, Felipe da Silva; SOUZA, Anna Carolina Carvalho de; MAGALHÃES JÚNIOR, Carlos Alberto de Oliveira; TELLES, Silvio de Cassio Costa. Representações sociais de graduandos em Educação Física sobre o meio ambiente e a relação homem, esporte e natureza. RBEP, Brasília, v. 102, n. 260, p. 205-217, jan./abr. 2021. Seção: Estudos.

sentido do brincar e do jogar na infância humana como fundamentos para a construção da democracia social, $O$.

SILVEIRA, Carmem Lúcia Albrecht; LAUER, Munir José; ESQUINSANI, Rosimar Serena Siqueira. O sentido do brincar e do jogar na infância humana como fundamentos para a construção da democracia social. RBEP, Brasília, v. 102, n. 262, p. 787-801, set./dez. 2021. Seção: Estudos.

Sistemas Apostilados de Ensino e a autonomia ilusória: reflexões à luz de José Contreras.

ORTIZ, Gabriel Santos; DENARDIN, Luciano; SAVI NETO, Pedro. Sistemas Apostilados de Ensino e a autonomia ilusória: reflexões à luz de José Contreras. RBEP, Brasília, v. 102, n. 262, p. 607-625, set./dez. 2021. Seção: Estudos

Tessitura e subsídios de um produto literário infantojuvenil para o ensino da história e cultura africana e afro-brasileira.

DIAS, Thiago Leandro da Silva; SOUZA, Rogério Santos. Tessitura e subsídios de um produto literário infantojuvenil para o ensino da história e cultura africana e afro-brasileira. RBEP, Brasília, v. 102, n. 261, p. 376397, maio/ago. 2021. Seção: Estudos.

vivências como metodologia de ensino da extensão rural: a aproximação entre estudantes e agricultores para a compreensão da realidade social, As.

FACCO, Hector dos Santos; DISKA, Nathana Marina; SILVA, Gustavo Pinto da. As vivências como metodologia de ensino da extensão rural: a aproximação entre estudantes e agricultores para a compreensão da realidade social. $R B E P$, Brasília, v. 102, n. 262, p. 821-838, set./dez. 2021.

Seção: Relatos de Experiência.

Vivências e memórias entre a Escola Monsenhor Lopes e a Comunidade Forte.

LOPES, Suzana Gomes; SILVA, Alexandre Leite dos Santos; SOUSA, Caroline Lucena de. Vivências e memórias entre a Escola Monsenhor Lopes e a Comunidade Forte. RBEP, Brasília, v. 102, n. 260, p. 43-62, jan./abr. 2021. Seção: Estudos. 